\title{
Response of Insect Pests to Botanical Insecticide Application on Leaf and Pod Soybean (Glycine max L.) of Organic Farming System
}

\author{
Asmanizar $^{1 *}$, Syamsafitri ${ }^{1}$, A Arianto ${ }^{1}$ \\ ${ }^{l}$ Faculty of Agriculture, Universitas Islam Sumatera Utara, Jl. Karya Wisata, Gedung Johor Medan, Indonesia \\ "Corresponding author.E-mail: asmanizar_az@fp.uisu.ac.id
}

\begin{abstract}
Leaf and pod insect pests are important on soybean (Glycine max L.) in Indonesia, causing loss of seed production. The study was carried out to evaluate the potential of water crude extract mixture of Azadirachta indica seed, Cymbopogon nardus plant and Alpinia galanga rhizome to control leaf and pod insect pests on soybean. The study was conducted in the organic farming system cultivation of soybean and it was arranged with Randomized Block Design. The concentrations of crude extract were 5, 10, 20 and 40\% (v/v) applied on soybean. The result showed that crude extract significantly affected on the damages of leaf and pod caused by the insect pest and seed production. The 20 and $40 \%$ of extracts concentrations resulted in 16.07 and $14.97 \%$ leaf damage caused by insect, pod damage of 5.38 and $5.33 \%$ and 7.56 and $6.77 \%$ caused by sucking insect and pod borer insect, respectively. Those concentrations yielded 436.0 and $540.6 \mathrm{~g}$ of seed production $/ 3 \mathrm{~m}^{2}$ plot size, respectively. This study showed that the mixture of crude extracts has the potential to be used in controlling insect pests on soybean.
\end{abstract}

Keywords: Alpinia galanga, Azadirachta indicata, crude extracts mixture, cymbopogon nardus, seed production

\section{INTRODUCTION}

Soybean Glycine max (L.) Merr. is the most important legume crop and major source of protein. The most known soybean products in Indonesia are tempe and tofu (tahu). The consumption of soybean in 2016-2017 is 2.9 million tons. Despite Indonesia has program to be self-sufficient on soybean, Indonesia still imports soybean for its domestic consumption due to low production of soybean. Indonesia government has imported the average of 2.3 and 2.7 million tons soybean in 2016 and 2017, respectively [1,2].

Pest is one of the limiting factors in the effort to optimize soybean production in Indonesia. Leaf and pod damages of soybean caused by insect pests showed significant yield losses (up to 80\%) [3, 4]. In order to control the pests, most farmer in Indonesia applied synthetic insecticides. The wide spread use of synthetic insecticide may cause a serious hazard to both man and wildlife. It may cause insect resistance, resurgence, decreasing of natural enemy population and other environtmental problem [5]. By using synthetic insecticide, it is costly and reduces farmer profit. It is important to find the new bioactive substances as alternative insecticide which is compatible with Integrated Pest Management Program.

There are some evidences that the plant semiochemicals content bioactive substances affecting insests. According to
Prakash and Rao [6] , plant products as botanical insecticides offer many advantages over synthetic chemicals. Botanical pesticides in general possess low mammalian toxicity and less health hazard and environmental pollution. Application of botanical insecticides is less risk when use in natural forms. The occurerence of pest resurgence of non-target organisms has not been reported, except for synthetic pyrethrins. Botanical pesticides are less expensive and ready to be made due to the materials are available in developing countries. Many plant materials show promising effects to insects. Higher plants are a rich source of novel insecticides [7]. Botanical insecticides show a broad range of pest insect control, are harmless to non-target organism, fairly specific in their mode of action. Moreover, they are easily to produce by farmer [8].

Insecticidal activity of Annonaceaous seed extract or powder had been reported by some researchers. Mariapan and Saxena [9] reported that mixtures of seed oil of custard-apple Annona squamosa and Neem Azadirachta indica were significantly effective in reducing the survival of leafhopper Nephotettix virescens. Rhizome powder of Alpinia galanga mixture with stored grain $1 \%(\mathrm{w} / \mathrm{w})$ was found to protect the grains against infestations of Sitophylus oryzae and Corcyra cephalonica and showed $100 \%$ mortality to both insects up to 45 days [6]. Cymbopogon nardus contains essential oil as 
geraniol $35.7 \%$, trans-citral $22.7 \%$, cis-citral $14.2 \%$, geranil asetat $9.7 \%$, citronnelal $5.8 \%$, citronnelol $4.6 \%$ [10]. The use of botanical insecticide in soybean organic farming is expected to maintain soybean yield potential.

The purpose of this work was to evaluate the potency of crude extract mixture of A. indica, $C$. nardus and A. galanga in controlling leaf and pod soybean insect pests in organic farming.

\subsection{Materials and Methods}

The research was conducted at field research station of Agriculture Faculty, Islamic University of North Sumatra, Gedung Djohor Medan, Indonesia, from June to August 2018. The plot preparation was done by loosen the soil. Organic fertilizers containing cow manure were applied $3 \mathrm{~kg} /$ plot at 2 weeks before planting. Completely Randomized Block Design was used in this research with five concentrations of crude extracts and replicated five times. The soybean variety planted was Anjasmoro. The plot size was $1.5 \times 2 \mathrm{~m}^{2}$ and the space between plants was $30 \mathrm{~cm}$ x $40 \mathrm{~cm}$. The seed was 3 seeds per hole. After planting the seed, the soil was covered with rice straw to avoid the bean fly attacks. After 2 weeks only one soybean plant was left.

Azadirachta indica (fruits), Cymbopogon nardus (aerial part of plant), and Alpinia galanga (rhizome) were obtained around Medan City. Preparation of crude extract was adopted from Astuti et al. [11]. A. indica (240 g), C. nardus (180 g) and A. galanga (180 g) plant materials were washed with tap water and cut into a small size and smoothered with electric blender. All grinded plant put together in a jar then added with $600 \mathrm{ml}$ of distilled water and soaked for $24 \mathrm{hr}$ then filtered. The crude extract was diluted with distilled water to obtain concentratios of 5,10,20 and 40\% (ml crude extract $/ \mathrm{ml}$ solution). Application of crude extract solution by soaking seeds 30 minutes before planting, then by spraying the extract mixtures at 15 days after planting (DAP) until 71 DAP with 14 days interval between applications. The equipment used was Knapsack Sprayer with flat fan nozzle of 5/64inch orifice diameter and spray volume of 5001/ha. The number of samples was 5 plants/plot. The observed variables were leaf damage intensity and pod damage percentage caused by the pest and seed production.

Statistical analysis was carried out by using ANOVA $(\mathrm{P}<0.05)$. Duncan's Multiple Range Test (DMRT) at 5\% confidence interval was used to determine the difference of variable from each crude extract concentration. All statistical analysis was done by using SPSS Statistic 24 Program.

\subsection{Our Contribution}

This research presents to provide the Soybean insect pest management by using botanical insecticide which is environmentally friendly. These botanical insecticides easily produce by farmer and the plants are locally available.

\subsection{Paper Structure}

The paper is organized as follow: Section 2 introduces the importance of soybean in Indonesia, and insect pest as one of the limiting factors in the efforts to get the optimum production. This section explains it is important to find the plant substances as alternative synthetic insecticide which is compatible with Integrated Pest Management (IPM). Section 3 presents the research methodology and statistical analysis used to find the effect of botanical insecticides against insect pests. Section 4 explains the result of study and comparing with another similar studies about the bioactive components in controlling insect pests. Finally, in the section 5 concludes the result.

\section{RESULTS AND DISCUSSION}

There was a significantly difference on leaf damage intensity caused by insect pests at 42,56 , and 70 day after treatment (DAT) $(\mathrm{F}=3.45,7.49$, and 19.17, $\mathrm{df}=4 \& 16, \mathrm{P}<$ $0.05)$ among plant extract concentrations. The mean of leaf damage intensity was shown on Table 1 .

Application of botanical insecticide caused a significance effects on leaf damaged at 42 DAT. Botanical insecticide application at $10 \%$ caused lower leaf damage (17.26\%) than control $(23.77 \%)$. At 70 DAT, both of botanical insecticide concentrations reduced leaf damage about 40.94 to $44.98 \%$ over control. The extract mixture of A. indica, $C$. nardus, and A. galanga showed the effectiveness against insect which caused leaf damage. The insects found attacked the plant were Lamprosema indicata and Valanga nigricornis. Azadirachtin is the first active ingredient isolated from the neem and it has been proven to be the main constituent for controlling insect pest. The bioactive chemicals contained in these plants have been reported by several researchers. From numerous field trials, larvae of most lepidopterous pests are highly sensitive to neem seed [5]. Weekly application of $4 \%$ methanolic neem kernel extracts almost completely protected the cabbage crop against the pest [12]. Chandramohan and Sivasubramanian [13] reported that aqueous neem leaf extracts were effective to protect the groundnut from leaf miner. 
Aqueous extract serves as a good antifeedant against pest of vegetables crops. A. galanga rhizome contains abundant bioactive compounds, such as 1,8-cineole which possess strong contact toxicity against Lasioderma serricorne [14]. Abdullah et al. [15] added that the 1,8-cineole possess antifeedant and repellent effects against termites Coptotermes gestrodes and C. curvignatus. Meanwhile, Cymbopogon nardus (citronella grass) contains cymbopogone and cymbopogonol, $\alpha$ and $\beta$-citrals, myrcene, linalool, lynalyl acetate, citronellal and nerol. Labinas and Crocomo [16] reported that Java grass Cymbopogon winterianus contains citronellal (42.15\%), citronellol $(22.03 \%)$ and geraniol $(16.44 \%)$ and showed repellency and insecticide properties to Spodoptera frugiferda larvae. Setiawati et al. [17] reported that $C$. nardus oil effective to control Heliccoverpa arnigera. The leaf damage on control treatment was about $27.21 \%$, it's due to new leaf growth.

There was a significant difference on pod damage caused by sucking insect and pod borer, and seed production $(\mathrm{F}=11.52,12.30$, and $11.09 \mathrm{df}=4 \& 16, \mathrm{P}<0.05)$ among plant extract concentrations. The means of pod damage and seed production was showed at Table 2 .

The average number of pod was about $80-100$ pods per plant. Botanical insecticide application affected pod damage caused by sucking and pod borrer insects. Botanical insecticides at $20 \%$ reduced pod damage by $63.47 \%$ and $56.57 \%$ caused by sucking and pod borer insects, respectively over control. Mollah et al. [18] sprayed $2.5 \mathrm{ml} / 1$ water of azadirachtin fresh (collected from the Crashing mill) and azadirachtin stored (16 months stored azadirachtin was collected from laboratory) at 10 days interval from first flowering to the last harvest of Lablab bean reduced number of Green Stink Bug 36.73 and 49.64\%, respectively over control. It was showed that $C$. nardus and A. galanga have potential to be effective to the soybean insect pest. Papulwar et al. [19] reported that citronella grass oil at $1 \%$ caused $100 \%$ mortality of pod borer Heliothis armigera larvae. It was due to the antifeedant and repellent activities of citronella grass. A. galanga essential oil at $20 \%$ caused $100 \%$ mortality of Crocidolomia pavonana larvae [20].

The result of seed production showed that botanical insecticides at 20 and $40 \%$ yielded 436.0 and $540.6 \mathrm{~g}$ (1.45 and 1.8 ton/ha), respectively (Table 2). The average of North Sumatera soybean seed production in 2017 was 1.28 ton/ha [21]. The reduction of leaf and pod damages caused by insect pest resulted in high seed production. The mixture of $A$. indicata, C. nardus and A. galanga showed to have potential to control soybean insect pest effectively.

Table 1 Leaf damaged caused by insect after treating with botanical insecticides

\begin{tabular}{|c|c|c|l|l|l|}
\hline \multirow{2}{*}{$\begin{array}{c}\text { Crude extracts } \\
\text { Conc. }(\%)\end{array}$} & \multicolumn{5}{|c|}{ Leaf damage intensity $(\% \pm$ SEM)* } \\
\cline { 2 - 6 } & 14 DAT & 28 DAT & 42 DAT & 56 DAT & 70 DAT \\
\hline 0 & $2.59 \pm 0.22$ & $14.26 \pm 1.81$ & $23.77 \pm 3.54 \mathrm{a}$ & $23.13 \pm 1.96 \mathrm{a}$ & $27.21 \pm 1.51 \mathrm{a}$ \\
\hline 5 & $2.23 \pm 0.53$ & $16.71 \pm 1.74$ & $19.67 \pm 2.41 \mathrm{ab}$ & $19.19 \pm 0.42 \mathrm{a}$ & $22.11 \pm 0.94 \mathrm{~b}$ \\
\hline 10 & $2.30 \pm 0.55$ & $16.55 \pm 2.03$ & $17.26 \pm 2.00 \mathrm{~b}$ & $20.87 \pm 1.91 \mathrm{a}$ & $22.74 \pm 1.50 \mathrm{~b}$ \\
\hline 20 & $2.58 \pm 0.26$ & $12.36 \pm 2.20$ & $15.70 \pm 2.08 \mathrm{~b}$ & $15.46 \pm 0.38 \mathrm{~b}$ & $16.07 \pm 0.79 \mathrm{c}$ \\
\hline 40 & $2.21 \pm 0.31$ & $12.21 \pm 2.10$ & $15.41 \pm 2.70 \mathrm{~b}$ & $14.14 \pm 1.25 \mathrm{~b}$ & $14.97 \pm 0.90 \mathrm{c}$ \\
\hline
\end{tabular}

* Means in a column followed by different letters are significantly different $(\mathrm{P}=0.05)$ by Duncan's Multiple Range (DMRT) Test. SEM = Standart Error of Mean; DAT= Day AfterTreatment

Table 2 Pod damage caused by insect after treated with botanical insecticides

\begin{tabular}{|c|c|c|c|}
\hline $\begin{array}{c}\text { Crude extracts } \\
\text { Conc. }(\%)\end{array}$ & $\begin{array}{c}\text { Pod damage caused by } \\
\text { sucking insect pest }(\% \pm \\
\text { SEM)* }\end{array}$ & $\begin{array}{c}\text { Pod damage caused by } \\
\text { borer insect pest }(\% \pm \\
\text { SEM)* }\end{array}$ & Seed production/plot $(\mathbf{g} \pm$ SEM)* \\
\hline 0 & $14.59 \pm 2.23 \mathrm{a}$ & $17.41 \pm 1.72 \mathrm{a}$ & $262.2 \pm 41.62 \mathrm{c}$ \\
\hline 5 & $8.43 \pm 0.64 \mathrm{~b}$ & $13.26 \pm 1.22 \mathrm{a}$ & $314.8 \pm 35.30 \mathrm{c}$ \\
\hline 10 & $9.24 \pm 1.92 \mathrm{~b}$ & $13.81 \pm 1.99 \mathrm{a}$ & $330.6 \pm 43.50 \mathrm{c}$ \\
\hline 20 & $5.38 \pm 0.99 \mathrm{c}$ & $7.56 \pm 1.14 \mathrm{~b}$ & $436.0 \pm 16.86 \mathrm{~b}$ \\
\hline 40 & $5.33 \pm 0.81 \mathrm{c}$ & $6.77 \pm 0.85 \mathrm{~b}$ & $540.6 \pm 45.17 \mathrm{a}$ \\
\hline
\end{tabular}

*Means in a column followed by different letters are significantly different $(\mathrm{P}=0.05)$ by Duncan's Multiple Range $(\mathrm{DMRT})$ Test. SEM = Standart Error of Mean. 
No synthetic pesticide and synthetic fertilizer was used in this study. Therefore, farmer would receive more benefits.

\section{CONCLUSION}

Water crude extract mixtures of Azadirachta indica seed, Cymbopogon nardus plant and Alpinia galanga rhizome at 20 and $40 \%$ of concentration showed a potency to be used in controling leaf and pod insect pests on soybean.

\section{ACKNOWLEDGMENT}

We thank to Dean of Faculty of Agriculture, Islamic University of North Sumatra for supporting field trial, given advised and motivation.

\section{REFERENCES}

[1] T. Sudaryanto, D.K.S. Swastika, Ekonomi Kedelai di Indonesia, Pusat Analisis Sosial-Ekonomi dan Kebijakan Pertanian, Bogor, 2007.

[2] Badan Pusat Statistik, Impor Kedelai Menurut Negara Asal Utama 2010-2018, 2018, https://www.bps.go.id/ statictable/2019/02/14/2015/impor-kedelai-menurutnegara-asal-utama-2010-2018.html

[3] W. Tengkano, M. Soerhardjan, Jenis hama utama pada berbagai fase pertumbuhan tanaman kedelai, In $\mathrm{S}$. Somaatmadja., M. Ismunadji, Sumarno, M. Syam., S.O. Manurung, Yuswadi (Eds.), Kedelai, Badan Penelitian dan Pengembangan Pertanian, Pusat Penelitian dan pengembangan Tanaman Pangan, 1985, pp. 295-318

[4] L. Haloho, Peluang Pengembangan Kedelai di Sumatera, Prosiding Seminar Hasil Penelitian Tanaman Aneka Kacang dan Umbi, 2014.

[5] D.A. Dodia, I.S. Patel, G.M. Patel, Botanical Pesticides for Pest Management, Jodhpur: Pawan Kumar Scientific Pub, 2008.

[6] A. Prakash, J. Rao, Botanical Pesticides in Agriculture, New York: Lewis Publishers, 1997.

[7] S. Dev, O. Koul, Insecticides of Natural Origin, OPA (Overseas Publisher Association) Amsterdam, Publish in Nederland by Harwood Academic Publishers, 1997.

[8] F.A. Talukder, P.E. Howse, Repellent, toxic, and food protectant effects of pithraj Anapahamixis polystachya extracts against pulse beetle, Callosobruchus chinensis in storage, J. Chem. Ecol. 4 (1994) 899-908

[9] V. Mariapan, R.C. Saxena, Effect of mixtures of Custrad-Apple oil and Neem Oil on survival of
Nephotettix virescens (Homoptera: Cicadellidae) and on Rice Tungro Virus Transmission. J. Econ. Entomol. 77 (1984) 519-521

[10] K. Nakahara, N.S. Alzoreky, T. Yoshihashi, H.T.T. Nguyen, G. Trakoontivakorn, Chemical Composition and Antifungal Activity of Essential Oil from Cymbopogon nardus (Citronella Grass). Jpn. Agric. Res. Q. 37(4) (2003) 249-252

[11] U.P. Astuti, T. Wahyuni, B. Honorita, Petunjuk Teknis Pembuatan Pestisida Nabati, Balai Pengkajian Teknologi Pertanian BPTP) Bengkulu, Balai Besar Pengkajian dan Pengembangan Teknologi Pertanian Badan Penelitian dan Pengembangan Pertanian, Kementrian Pertanian, 2013.

[12] R.C. Saxena, 2015. Neem for Sustainable Pest Management and Environmental Conservation, ECHO Asia Note Articles, 2015, https://www.echocommunity.org/en/ resources/8070b92959de4c4c893db5cd97542a41

[13] N. Chandramohan, P. Sivasubramanian, Evaluation of neem products against leaf miner, Aproacrema modicella D, Neem Newslett. 4(4) (1987) 44

[14] Y. Wu, Y. Wang, Z.H. Li, C.F. Wang, J.Y. Wei, X.L. Li, P.J. Wang, Z.F. Zhou, S.S. Du, D.Y. Huang, Z.W. Deng, Composition of the essential oil from Alpinia galanga rhizomes and its bioactivity on Lasioderma serricorne, Bull. Insectology, 67(2) (2004) 247-254

[15] F. Abdullah, P. Subramanian, H. Ibrahim, S.N. Abdul Malek, G.S. Lee, S.L. Hong, Chemical composition, antifeedant, repellent, and toxicity activities of the rhizomes of galangal, Alpinia galanga against Asian subterranean termites, Coptotermes gestroi and Coptotermes curvignathus (Isoptera: Rhinotermitidae), J. Insect Sci. 15 (2015) 1-7

[16] M.A. Labinas, W.B. Crocomo, Effect of java grass (Cymbopogon winterianus) essential oil on fall armyworm Spodoptera frugiperda (J. E. Smith, 1979) (Lepidoptera, Noctuidae). 2002, Acta Scientiarum, Maringá. 24(5) 1401-1405

[17] W. Setiawati, R. Murtiningsih, A. Hasyim, Laboratory and field evaluation of essential oil from Cymbopogon nardus as oviposition deterrent and ovicidal activities against Helicoverpa armigera Hubner on chili pepper, IJAS. 12(1) (2011) 9-16, DOI: http://dx.doi.org/10.21082/ijas. v12n1.2011.p9-16

[18] M.M.I Mollah, M.M. Rahman, S. Khatun, M. Mala, M.R. Akon, Toxicity of botanical and chemical insecticides on stink bug complex (Heteroptera: Pentatomidae) in lablab bean (Lablab purpureus Lin.) field, J. Entomol. Zool. Stud. 5(2) (2017) 537-541

[19] P.P. Papulwar, B.U. Rathod, N.R. Dattagonde, Studies 
on insecticidal properties of citronella grass (lemon grass) essential oils against gram pod borer (Helicoverpa armigera), Int. J. Chem. Stud. 2(1) (2018) 44-46

[20] W. Rassami, J. Sawasdikarn, A. Piamporm, M. Sanguan-Hong, Larvicidal Activity of Five Medicinal Plants of Zingiberaceae on Cabbage Moth, Crocidolomia paponana (F.) in Laboratory Condition, IJAT. 12(7.1) (2016) 1201-1208

[21] Badan Pusat Statistik, Luas panen, rata-rata produksi dan produksi kacang kedelai 2007-2017, 2017, https://sumut.bps.go.id/statictable/2018/09/04/1018/lua s-panen-rata-rata-produksi-dan-produksi-kacangkedelai-2007-2017.html 